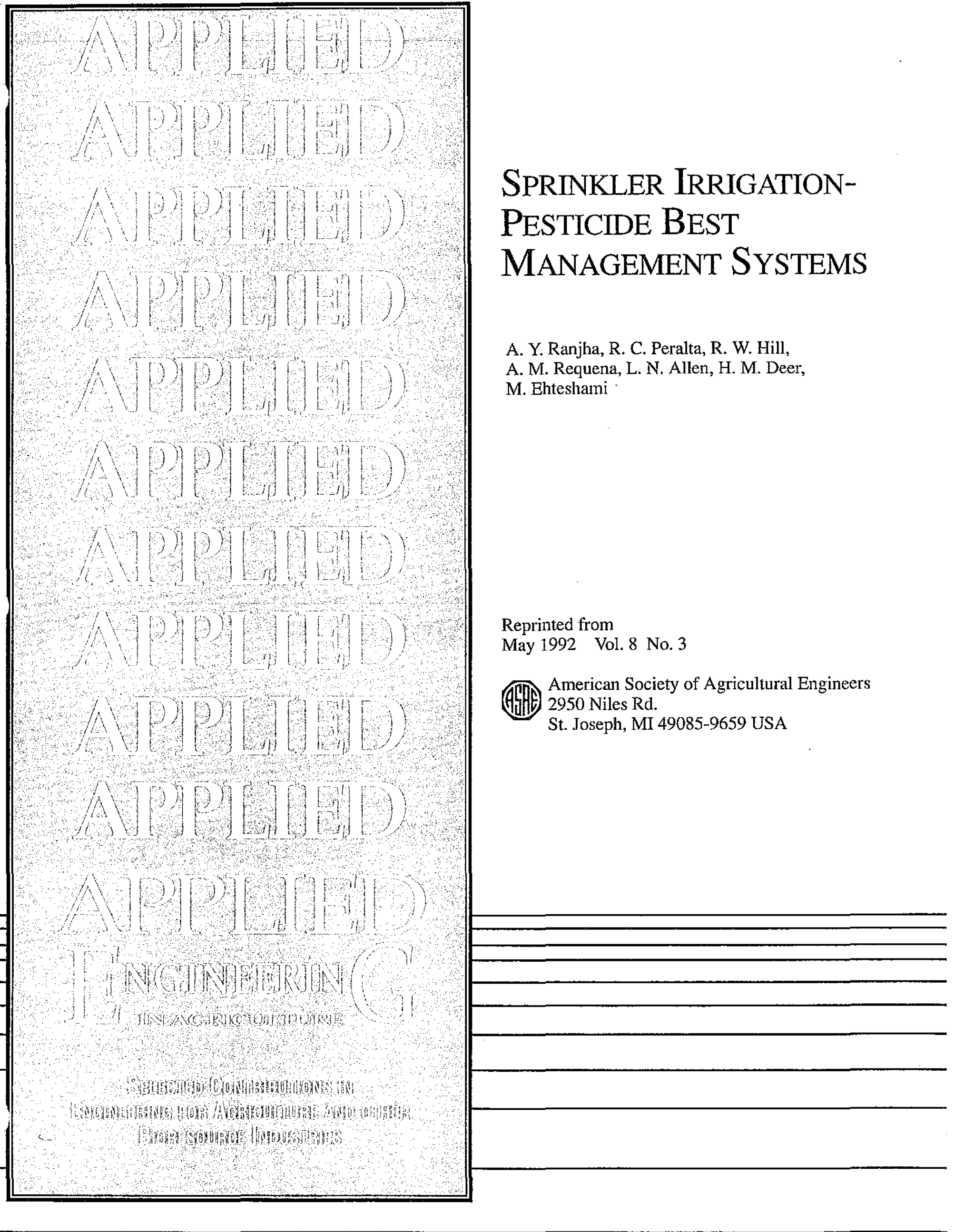




\section{Custom Reprints}

Presentation quality reprints are now available.

$81 / 2$ " $\times 11$ "format

Mail Orders Only

Purchase Order Required with Order Form

1-4 page reprint per $100 \ldots \ldots \ldots \$ 74.00$

5- 8 page reprint per $100 \ldots \ldots \ldots \$ 127.00$

$9-12$ page reprint per $100 \ldots \ldots \ldots \$ 191.00$

$13-16$ page reprint per $100 \ldots \ldots \ldots \$ 252.00$

$17-20$ page reprint per $100 \ldots \ldots \ldots 312.00$

Purchase Order No.

Name

Company

Address

City

State/Province

Zip/Postal Code Country

Telephone

$\square \quad$ I am an ASAE member

$\square \quad$ Nonmember

Member No. $\square, \square, \square, \square, \square$

$\square$ Send ASAE membership information

Total Copies

Page Numbers

Cost \$

Michigan residents only - add 4\% sales tax

Postage and Handling

Add $10 \%$ for order shipped outside US

TOTAL

All payments must be in US dollars.

Prices subject to change

\section{METHOD OF PAYMENT}

Check attached payable to ASAE

Mastercard $\square$ VISA $\square$ American Express $\square$ Diners Club

Credit Card Number

Expiration Date

Cardholder Name (if different)

Authorized Signature
Complete and return this form to:

ASAE Order Department

2950 Niles Road

St. Joseph, MI 49085-9659

FAX: 616.429.3852

Please FAX both sides of this form 


\title{
SPRINKLER IRRIgATION-Pesticide Best MANAGEMENT Systems
}

\author{
A. Y. Ranjha, R. C. Peralta, R. W. Hill, A. M. Requena, L. N. Allen, H. M. Deer, M. Ehteshami \\ MEMBER \\ ASAE
}

\begin{abstract}
The relative reduction in potential ground water contamination due to pesticides at several sites in Utah was determined by comparing alternative irrigation system designs, water management practices, and pesticides.

Alternative sprinkler irrigation distribution coefficients were used to estimate irrigation application depths. The movement of pesticides through soils following sprinkler irrigations was simulated with a one-dimensional model.

Pesticide contamination of groundwater can be reduced by careful selection of pesticides, using properly designed irrigation systems, and improved water management techniques. Procedures for selecting an appropriate sprinkler system design and pesticide are presented.

KeYwords. Pesticides, Leaching, Sprinkler irrigation, Irrigation depth, Irrigation system design, Soil, Water management.
\end{abstract}

\section{INTRODUCTION}

$\mathrm{P}$ esticides minimize crop losses caused by insects, pathogens, weeds, and other pests, but pesticides also can contaminate groundwater. Potential contamination is of particular concern in areas where groundwater is the main source of water supply for domestic needs.

There are more than 45,000 registered pesticides (USEPA, 1987). Almost 500 million $\mathrm{kg}$ of pesticides are used in the U.S. each year (Pimentel and Levitan, 1986). Of these, approximately $60 \%$ are herbicides, $24 \%$ are insecticides, and $16 \%$ are fungicides. About $68 \%$ of these are used on agricultural land, where every dollar spent on pesticides returns about four dollars in agricultural production (Pimentel and Levitan, 1986).

Zaki et al. (1982) found aldicarb, a carbamate pesticide, in the groundwater in Suffolk County, New York. Aldicarb levels exceeded the state-recommended safety limits in $13 \%$ of 8000 tested wells. According to Sum (1986), the USEPA reported that 17 pesticides were detected in the

Article was submitted for publication in May 1991; reviewed and approved for publication by the Soil and Water Div. of ASAE in January 1992.

The authors are Ahmad Yar Ranjha, Visiting Associate Professor, Richard C. Peralta, Professor, Robert W. Hill, Professor, Antonio Maria Requena, former Graduate Student, L. N. Allen, Extension/ Research Irrigation Engineer, Agricultural and Irrigation Engineering Dept., Howard M. Deer, Extension Pesticide Specialist, Dept. of Animal, Dairy, and Veterinary Sciences, and Majid Ehteshami, former Research Associate, Agricultural and Irrigation Engineering Dept., Utah State University, Logan. groundwater of 23 states. Pesticide concentrations ranged from a trace to several hundred parts per million in groundwater. In Oahu, Hawaii, pumping was discontinued at several domestic water wells due to groundwater contamination by pesticides, probably nematicides (Oki and Giambelluca, 1987), used in pineapple production (Lau and Mink, 1987). In the Mahantango Creek watershed, Pennsylvania, atrazine was detected in 14 of 20 wells that were tested (Pionke et al., 1988).

About $50 \%$ of the U.S. population obtains drinking water from groundwater (Leonard et al., 1988). This percentage is $63 \%$ in Utah (Waddell, 1987). Most rural residents totally rely on groundwater for domestic needs.

Groundwater contamination by pesticides depends on such factors as agricultural practices, soils, plant uptake, geology, hydrology, climate, topography, and pesticide properties.

\section{Objective}

This study examined how the use of appropriate management techniques (sprinkler irrigation system design and pesticide selection) affected potential pesticide contamination of groundwater. The main objective of this article is to present an integrated approach for the selection and management of appropriate sprinkler irrigation systems and less mobile pesticides as a best management system (BMS). Use of such a BMS is environmentally safer than less integrated approaches.

\section{METHODS}

\section{IDENTIFICATION OF STUDY SitEs}

Sites in the 29 counties of Utah that may be subject to groundwater contamination were identified and ranked (Eisele et al., 1989). First, a rapid screening procedure, DRASTIC (Aller et al., 1985), was used to identify sites with a high risk. Subsequently, a one-dimensional simulation model, CMLS (Nofziger and Hornsby, 1986, 1988), was used to simulate the movement of pesticides in unsaturated soils at locations where the risk of contamination was higher (Eisele et al., 1989). A comparison of DRASTIC and CMLS rankings was performed by Ehteshami et al. (1991).

Six agricultural areas were identified as having relatively high potential for groundwater contamination, based on the findings of Eisele et al. (1989) and Ehteshami et al. (1991). These study sites were located in Cache, Davis, Sevier, Utah, Washington, and Weber counties of Utah.

For each of the selected sites the necessary data were obtained and using CMLS, computer simulations 


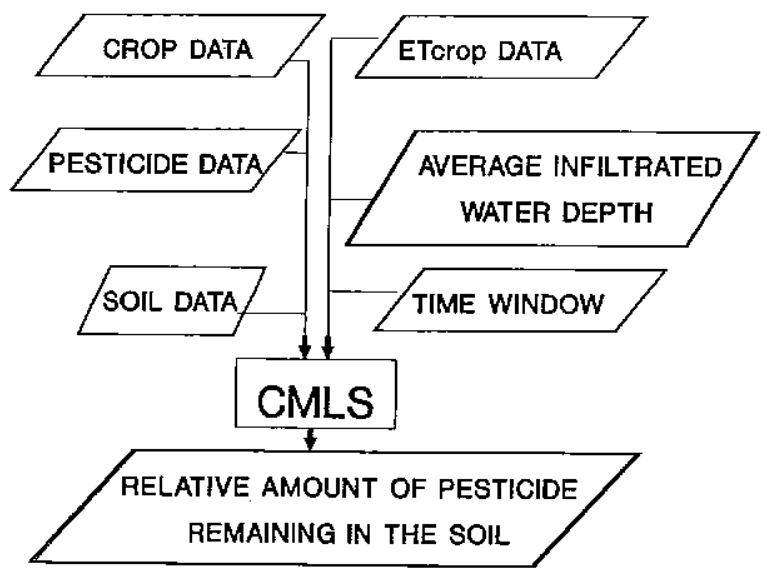

Figure 1-Schematic representation of the procedure to estimate relative amount (RA) of pesticides remaining in the soil.

performed for alternative water management practices, pesticides, and crops. Stepwise representation of the simulation procedure to estimate the potential existence of pesticides in soils is illustrated in figure 1. The amount of infiltration was estimated using a distribution coefficient (Ha) approach (Hart and Reynolds, 1965). Infiltration values were then used in CMLS to predict pesticide movement. The relative potential for groundwater contamination was determined and relative importance of each factor on groundwater contamination was assessed.

\section{Simulation of Pesticide Movement Using CMLS}

Based on the study of Eisele et al. (1989), we selected the CMLS as the most appropriate pesticide transport model for this study. The following assumptions (abbreviated by the author) are used in CMLS (Nofziger and Hornsby, 1986, 1988):

- All the soil water residing in pore spaces participate in the transportation process. No preferential flow is assumed.

- Water entering the soil redistributes instantaneously to field capacity.

- Water is removed by evapotranspiration from each layer in the root zone in proportion to the relative amount of water available in that layer.

- Upward movement of soil water does not occur anywhere in the soil profile.

- The adsorption process can be described by a linear, reversible equilibrium model.

- The half-life time for biological degradation of the chemical is constant with time and soil depth.

CMLS simulates (a) the movement of the chemical, and (b) the degradation of the chemical. Chemicals move only with soil-water movement. A soil-moisture volume balance approach is used to calculate water movement. At the beginning of the simulation, each layer in the soil profile is assumed to be at field capacity. Soil moisture is depleted at the rate of daily crop evapotranspiration from the available soil water in each layer of the root zone. Water is available for plants if the water content in any layer of the root zone is in excess of the permanent wilting point. After an irrigation and/or rain occurs, the water content of each layer is adjusted, starting with the upper soil layer.
Due to adsorption processes, chemicals advance far less in depth than water. In CMLS, only the sorption and biodegradation processes of the chemicals are considered and diffusion of chemicals (usually insignificant for organic pesticides) is disregarded. A reversible equilibrium and linear adsorption model simulates the retardation of the chemical movement. The following equations predict chemical movement:

$$
\begin{gathered}
\text { if } W_{p}>0, \\
d^{s}-d^{s s}=W_{p} /\left(R F \theta^{f c}\right), \\
\text { if } W_{p} \leq 0, \\
d^{s}-d^{\prime s}=0, \\
R F=1+\left(B D K_{d} / \theta^{f c}\right), \\
K_{d}=K_{o c} f_{o c},
\end{gathered}
$$

where

$$
\begin{aligned}
& \mathrm{W}_{\mathrm{p}} \text { = amount of water passing the depth } \mathrm{ds} \\
& \text { (mm or in.), } \\
& \mathrm{d}^{\mathrm{s}} \quad=\text { solute front depth ( } \mathrm{mm} \text { or in.), } \\
& \mathrm{d}^{\prime} \mathrm{s}=\text { solute front depth prior to the adjustment } \\
& \text { (mm or in.), } \\
& R F=\text { retardation factor, } \theta^{\mathrm{fc}} \text { is the soil-water content } \\
& \text { on a volume basis at field capacity, } \\
& \mathrm{BD}=\text { soil bulk density }\left(\mathrm{g} / \mathrm{cm}^{3}\right) \text {, } \\
& \mathrm{Kd}=\text { partition coefficient of the chemical in soil } \\
& (\mathrm{mL} / \mathrm{g} \text { soil), } \\
& \mathrm{K}_{\mathrm{oc}}=\text { organic carbon partition coefficient }(\mathrm{mL} / \mathrm{g} \\
& \mathrm{OC}) \text {, and } \\
& f_{\mathrm{OC}}=\text { organic carbon fraction of the soil (OC fraction). }
\end{aligned}
$$

In the soil, chemicals are continuously exposed to degradation processes. Relative amount (RA), the fraction of the applied chemical remaining in a soil profile, is predicted by CMLS:

$$
\mathrm{RA}=\mathrm{e}^{-\operatorname{tr} \ln (2) / \mathrm{t}_{1 / 2},}
$$

where

$\operatorname{tr}=$ travel time since the chemical was applied (days), and

$t_{1 / 2}=$ the biological degradation half-life of the chemical (days).

In CMLS, the following parameters are used as input:

- soil properties (bulk density, water content at field capacity, permanent wilting point, and soil organic carbon content);

- chemical properties of the pesticide (partition coefficient and degradation half-life);

- climatic and cultural factors (plant root depth, daily rainfall + irrigation, and daily evapotranspiration amounts).

The outputs given by CMLS, among others, include, travel time (tr) for chemicals to move to selected depths and RA of pesticides remaining at those times in the soil profile. 
The average sprinkler irrigation depth applied over a field was estimated using the distribution coefficient (Ha) approach (Hart and Reynolds, 1965). Their approach recognizes that the average applied water depth on a field is a function of both uniformity coefficient (UC) and the percent of area that is at least adequately irrigated.

They assumed that the distribution of applied water depths in an overlapped sprinkler pattern approximates the normal distribution. Then the average applied depth of water, Vi ( $\mathrm{mm}$ or in.) can be determined by:

$$
\mathrm{Vi}=\text { Zreq } / \mathrm{Ha} \text {, }
$$

where

$$
\begin{aligned}
& \text { Zreq = required irrigation depth ( } \mathrm{mm} \text { or in.) at a given } \\
& \text { date, and } \\
& \mathrm{Ha}=\text { distribution coefficient (a fraction of the mean }
\end{aligned}
$$
applied depth).

Hart and Reynolds reported Ha values for a range of UC values (60 to $99.9 \%$ ) and an assumed range of a fraction of the field area ( 50 to $100 \%$ ) that can be adequately irrigated. The UC is given by the following empirical relationship (Christensen, 1942):

$$
U C=100\left(1.0-\sum|z-m| / \sum z\right)
$$

where

$\mathrm{UC}=$ uniformity coefficient (\%), $\mathrm{z} \quad=$ individual depth ( $\mathrm{mm}$ or in.) of catch observations from uniformity test, and

$\mathrm{m}=$ mean depth ( $\mathrm{mm}$ or in.) of observations.

In this study, Ha values reported by Hart and Reynolds (1965) were used to estimate average depth of water applied. We selected table combinations of fraction of area adequately irrigated $(50,60,70,80,90$, and $100 \%)$ and UC $(60,80$, and $96 \%)$. The UC values over $96 \%$ were omitted because irrigation uniformity higher than this is not economically feasible, as excessively close spacing of sprinklers is required.

For all combinations, the irrigation amount required in the soil profile was assumed $45 \mathrm{~mm}$ (1.8 in.) i.e., an irrigation was applied whenever the soil moisture depletion was $45 \mathrm{~mm}$ (1.8 in.). The average applied depth of irrigation ( $\mathrm{Vi}$ ) for each combination was computed by dividing Zreq ( $45 \mathrm{~mm}$ or $1.8 \mathrm{in}$.) by the appropriate Ha. For example, for UC value of $96 \%$ and fraction of area adequately irrigated of $100 \%$, the Ha value reported by Hart and Reynolds (1965) was 0.85 (Table 1). Therefore, the average applied depth of irrigation (Vi) for a Zreq of $45 \mathrm{~mm}$ (1.8 in.) is $53 \mathrm{~mm}$ (2.1 in.) i.e., $45 \mathrm{~mm} / 0.85$ $=53 \mathrm{~mm}$ (2.1 in.) (Table 1). These applied irrigation depths were used in CMLS to predict the RA of a pesticide for a known site, crop, irrigation system, and schedule.

Out of many analyses performed for each of the six selected areas, only representative results are presented

\begin{tabular}{|c|c|c|c|c|c|c|c|c|}
\hline $\begin{array}{l}\text { UC } \\
\text { (\%) }\end{array}$ & $\begin{array}{l}\text { Fraction of } \\
\text { Area Adeq- } \\
\text { Irrigated } \\
\text { (\%) }\end{array}$ & $\begin{array}{l}\text { Distribution } \\
\text { Coefficient } \\
\text { (Ha) } \\
\text { (fraction) }\end{array}$ & $\begin{array}{l}\text { Required } \\
\text { Depth } \\
\text { (Zreq) } \\
\text { (mm) }\end{array}$ & $\begin{array}{l}\text { Applied } \\
\text { Water Depth } \\
\text { (Vi) } \\
\text { (mm) }\end{array}$ & $\begin{array}{l}\text { Storage } \\
\text { Effic. } \\
\text { (Es) } \\
\text { (fraction) }\end{array}$ & $\begin{array}{c}\text { Amount } \\
\text { of Water } \\
\text { Stored } \\
(\mathrm{mm})\end{array}$ & $\begin{array}{c}\text { Average } \\
\text { Deep } \\
\text { Percolation } \\
\text { (mm) }\end{array}$ & $\begin{array}{l}\text { RA at } 2 \mathrm{~m} \\
\text { Soil } \\
\text { Depth } \\
\text { (fraction) }\end{array}$ \\
\hline 1 & 2 & 3 & 4 & 5 & 6 & 7 & 8 & 9 \\
\hline Given & Given & Given & Given & $(4 / 3)$ & (Given) & $(5 \times 6)$ & $(5-7)$ & Predicted \\
\hline 60 & 100 & - & 45 & - & - & - & - & - \\
\hline 60 & 90 & 0.357 & 45 & 126.05 & 0.333 & 41.97 & 84.08 & 0.75 \\
\hline 60 & 80 & 0.578 & 45 & 77.85 & 0.521 & 40.56 & 37.29 & 0.60 \\
\hline 60 & 70 & 0.737 & 45 & 61.06 & 0.641 & 39.14 & 21.92 & 0.55 \\
\hline 60 & 60 & 0.873 & 45 & 51.55 & 0.730 & 37.63 & 13.92 & 0.49 \\
\hline 60 & 50 & 1.000 & 45 & 45.00 & 0.799 & 35.96 & 9.04 & 0.43 \\
\hline 80 & 100 & 0.225 & 45 & 200,00 & 0.225 & 45.00 & 155.00 & 0.82 \\
\hline 80 & 90 & 0.679 & 45 & 66.27 & 0.667 & 44.20 & 22.07 & 0.55 \\
\hline 80 & 80 & 0.789 & 45 & 57.03 & 0.761 & 43.40 & 13.63 & 0.49 \\
\hline 80 & 70 & 0.869 & 45 & 51.78 & 0.821 & 42.51 & 9.27 & 0.43 \\
\hline 80 & 60 & 0.937 & 45 & 48.03 & 0.865 & 41.55 & 6.48 & 0.43 \\
\hline 80 & 50 & 1.000 & 45 & 45.00 & 0.900 & 40.50 & 4.50 & 0.43 \\
\hline 96 & 100 & 0.845 & 45 & 53.25 & 0.845 & 45.00 & 8.25 & 0.43 \\
\hline 96 & 90 & 0.936 & 45 & 48.08 & 0.933 & 44.86 & 3.22 & 0.39 \\
\hline 96 & 80 & 0.958 & 45 & 46.97 & 0.952 & 44.72 & 2,25 & 0.39 \\
\hline 96 & 70 & 0.974 & 45 & 46.20 & 0.964 & 44.54 & 1.66 & 0.39 \\
\hline 96 & 60 & 0.987 & 45 & 45.60 & 0.973 & 44.37 & 1.23 & 0.39 \\
\hline 96 & 50 & 1.000 & 45 & 45.00 & 0.980 & 44.10 & 0.90 & 0.39 \\
\hline
\end{tabular}
here. These illustrate the two methodologies presented in this article. The first methodology illustrates the selection

TABL,E 1. Effect of sclected sprinkler design parameters (UC and fraction of area adequately irrigated) on the average applied water depth, average deep percolation, and RA

Note: Source for data in columns 1, 2, 3, and 6: Hart and Reynolds (1965).

To convert $\mathrm{mm}$ to $\mathrm{in}$. or $\mathrm{m}$ to $\mathrm{ft}$, use the following conversions: $\mathrm{mm} / 25.4=\mathrm{in}$.; $\mathrm{m} \times 3.3=\mathrm{ft}$. 
of a sprinkler irrigation system design for a range of pesticide RA values for a given site, crop, and irrigation schedule. The second methodology illustrates the selection of a pesticide for a given irrigation system, schedule, site, crop, and desired RA. These methodologies are being used to develop decision-support computer models for devising integrated best management practices (BMPs) for various soils, crops, pesticides, irrigation systems, and schedules.

\section{RESULTS AND DisCUSSION \\ Sprinkler Irrigation Uniformity and Pesticide LEACHING}

Ideally, sprinklers would apply a uniform depth of water to all areas in a field. This would make it possible to meet crop and leaching requirements without excessive deep percolation. Unfortunately, sprinkler systems do not apply water uniformly. Different areas in the field receive varying irrigation depths.

Irrigation system design greatly affects pesticide leaching in irrigated areas. Pesticide leaching can be significantly reduced by efficient sprinkler irrigation design. Figure 2 illustrates how irrigation distribution coefficient (Ha) and the RA of pesticide remaining in the soil are affected by design parameters. Considered parameters are the fraction of area adequately irrigated (\%) and uniformity coefficient (\%).

In the following example, we have compared field average deep percolation values and their respective predicted pesticide leaching. Deep percolation is the difference between the amount of water infiltrated into the soil and the amount of water stored in the root zone of a crop after each irrigation. Thus, average deep percolation refers to the spatial average amount of infiltrating water that percolates below the root zone.

Soil nonhomogeneities and deviation from average deep percolation values may cause pesticides to leach more than predicted. Thus, presented results represent relative comparisons rather than exact predictions.

\section{EXAMple}

Consider a crop of alfalfa on Kidman (sandy loam) soil that is irrigated each time it requires (Zreq) $45 \mathrm{~mm}$ (1.8 in.) of the available soil water in its root zone. For illustration

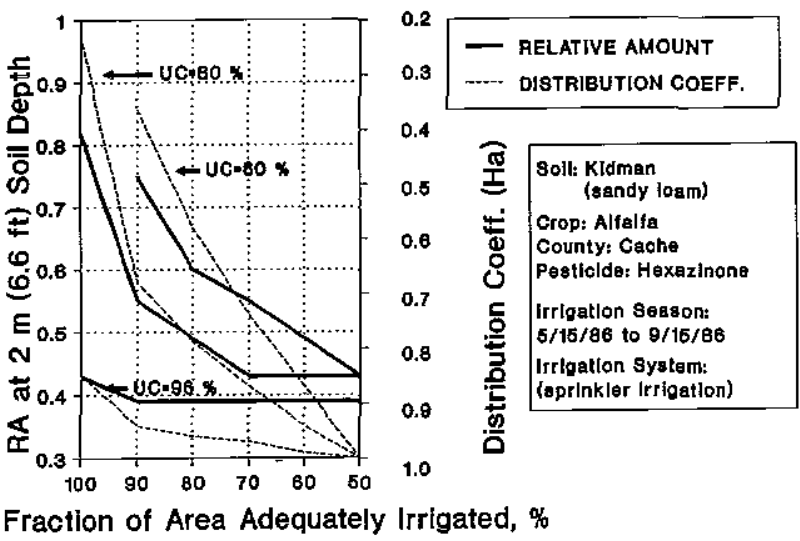

Figure 2-Effects of uniformity coefficient (UC) and percent of area adequately irrigated on distribution coefficient $(\mathrm{Ha})$ and on the relative amount (RA) of hexazinone remaining at $2 \mathrm{~m}(6.6 \mathrm{ft})$ soil depth under alfalfa irrigation season. purposes, we assume three different sprinkler systems which will supply the same amount of irrigation water. In other words, each of them uses the same irrigation schedule and has the same average irrigation depth to be applied at each irrigation. Each system has very similar distribution coefficients.

Three selected combinations of UC and fraction of area adequately irrigated $(96 \%, 100 \% ; 80 \%, 70 \%$; and $60 \%$, $60 \%$ ), respectively, represent the upper, middle, and lower range design parameter values for the three considered sprinkler systems (Table 1). The purpose of selecting these three combinations is to show that with almost the same average depth of water 52 or $53 \mathrm{~mm}(2.1 \mathrm{in}$.) applied at each irrigation, which combination is environmentally and economically better and more practical.

As shown in Table 1, with an ideal UC of $96 \%$ and almost $100 \%$ of the field area adequately irrigated, the average deep percolation is $8.3 \mathrm{~mm}(0.3 \mathrm{in}$.) per irrigation. With a more realistic UC of $80 \%$ and $70 \%$ of the field adequately irrigated, the average deep percolation is $9.3 \mathrm{~mm}(0.4 \mathrm{in}$.) per irrigation. With a poor UC of $60 \%$ and $60 \%$ of the field area adequately irrigated, the average deep percolation is $13.9 \mathrm{~mm}(0.6 \mathrm{in}$.) per irrigation. With the lower uniformities less water is available for crop use, crop yield is less (larger area under-irrigated), and more water percolates below the root zone. Therefore, poor sprinkler irrigation uniformities are environmentally and economically undesirable.

The average RA of pesticide reaching the $2 \mathrm{~m}(6.6 \mathrm{ft})$ soil depth (fig. 1) is $0.43,0.43$, and 0.49 for the respective combinations of UC and percent area adequately irrigated $(96 \%, 100 \%$; $80 \%, 70 \%$; and $60 \%, 60 \%)$. The RA for the first two combinations $(96 \%, 100 \%$ and $80 \%, 70 \%)$ is the same because the time required for the pesticide to move $2 \mathrm{~m}(6.6 \mathrm{ft})$ deep into the soil profile is the same.

Environmentally, either of these two combinations of UC and percent area adequately irrigated $(96 \%, 100 \%$ or $80 \%, 70 \%$ ) have the same impacts. However, economically and practically, the second combination of UC and percent area adequately irrigated $(80 \%$ and $70 \%)$ is more feasible (less sprinkler hardware is required). The ideal combination of UC $(96 \%)$ and percent area adequately irrigated $(100 \%)$ generally achieves the lowest RA of hexazinone (environmentally relatively inoffensive), although it might be expensive and requires much sprinkler hardware. Nevertheless, this sprinkler irrigation system design was used for all subsequently discussed CMLS simulations.

\section{Pesticide Alternatives}

A second situation exists when the irrigation system and schedule are in place and farmers must select an appropriate pesticide. Farmers usually have several pesticide selection options. Each chemical has different values of $\mathrm{K}_{\mathrm{oc}}$ and $\mathrm{t}_{1 / 2}$. To develop decision-support nomograms, many simulations were performed in which $K_{o c}$ varied from 1 to $100 \mathrm{~mL} / \mathrm{g} O C$ and $t_{1 / 2}$ ranged from 10 to 100,000 days. We assumed alfalfa was irrigated using a 1986 irrigation schedule in Cache County, Utah. The RA that remained when the pesticide reached soil depths of $0.5 \mathrm{~m}(1.7 \mathrm{ft})$ and $2.0 \mathrm{~m}(6.6 \mathrm{ft})$ was predicted (figs. 3 and 4, respectively). 
Figure 3 illustrates that for low $K_{o c}$ values ( $<75 \mathrm{~mL} / \mathrm{g} \mathrm{OC}$ ), as the $t_{1 / 2}$ decreases, the RA remaining at $0.5 \mathrm{~m}(1.7 \mathrm{ft})$ soil depth also decreases. For a given $\mathrm{t}_{1 / 2}$, as the $\mathrm{K}_{\mathrm{oc}}$ increases, the RA remaining at $0.5 \mathrm{~m}(1.7 \mathrm{ft})$ soil depth decreases. For higher $\mathrm{K}_{\mathrm{oc}}$ values $(<75 \mathrm{~mL} / \mathrm{g} \mathrm{OC}$ ), the predicted RA is 0.00 regardless of $t_{1 / 2}$. This shows that all alfalfa pesticides having $\mathrm{K}_{\mathrm{oc}}>75 \mathrm{~mL} / \mathrm{g}$ OC are safe to use, regardless of half-life.

Figure 4 shows similar results for RA values for pesticides reaching a $2 \mathrm{~m}(6.6 \mathrm{ft})$ soil depth (below the alfalfa root zone). No pesticide with $t_{1 / 2}$ of 10 days or less percolates to $2 \mathrm{~m}(6.6 \mathrm{ft})$. Short half life pesticides biodegrade long before they can percolate deeply at that site. The $2 \mathrm{~m}(6.6 \mathrm{ft})$ soil depth adsorbs more pesticides than the $0.5 \mathrm{~m}(1.7 \mathrm{ft})$ depth. In summary, only pesticides with $\mathrm{K}_{\mathrm{oc}}$ values lower than $15 \mathrm{~mL} / \mathrm{g} \mathrm{OC}$ and half-lives $\left(t_{t / 2}\right)$ longer than 10 days will leach below the alfalfa root zone and be likely to cause groundwater contamination.

\section{Sensitivity ANalyses}

Values for selected soil physical properties such as organic carbon content $(\%)$, bulk density $\left(\mathrm{g} / \mathrm{cm}^{3}\right)$, volumetric water content $(\%)$ at field capacity, and at wilting point for different soil textures were used in a sensitivity analysis presented below. Also evaluated is the effect of assuming an average deep percolation value despite the fact that even the best sprinkler system applies significantly different amounts of water to different parts of a field.

SoIL

The greater the clay and organic carbon content, the greater a soil's tendency to retain pesticides and the smaller the risk of groundwater contamination. Pesticides require more travel time when moving through heavy soils (e.g., clay soils), than through lighter soils (e.g., sand). The travel time, in turn, determines the time available for pesticide degradation via chemical and biological processes. Figure 5 illustrates how soil texture affects aldicarb RA values. Much more aldicarb reaches $2 \mathrm{~m}$ $(6.6 \mathrm{ft})$ depth in sand than in the heavier soils.

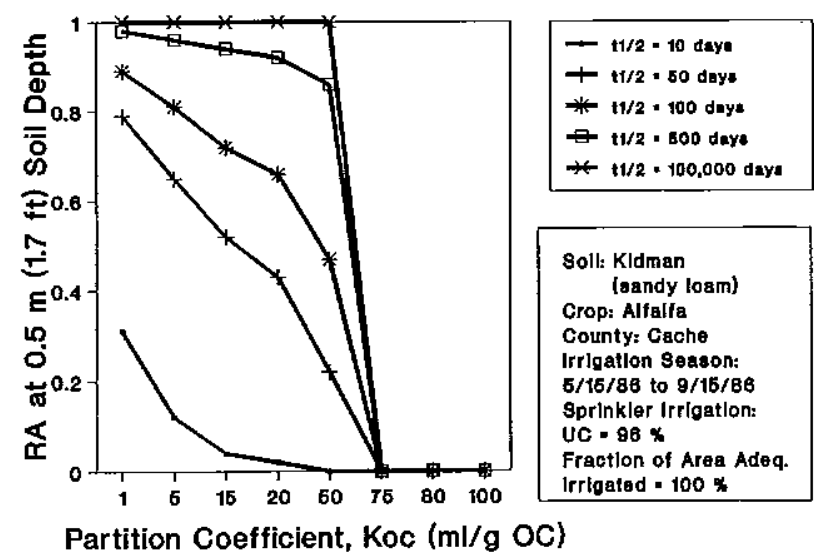

Figure 3-Effects of pesticide parameters on the relative amount (RA) remaining when a pesticide reaches $0.5 \mathrm{~m}(1.7 \mathrm{ft})$ soil depth for known site, system, and irrigation schedule.
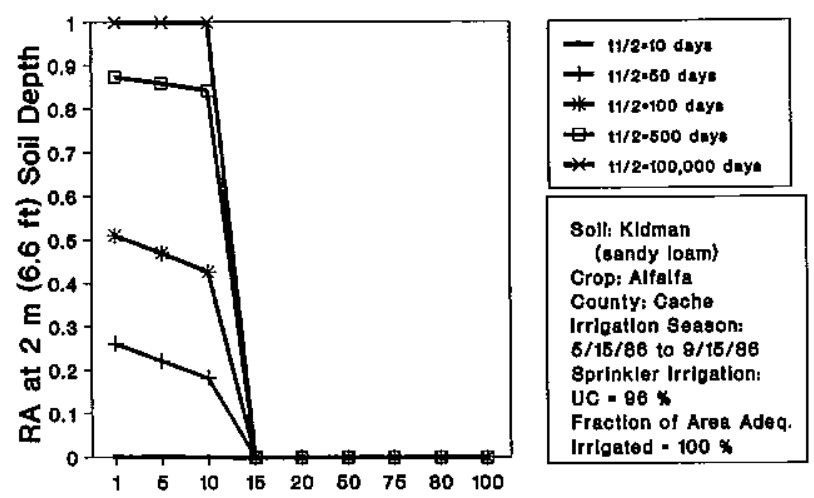

Partition Coefficient, Koc (ml/g OC)

Figure 4-Effects of pesticide parameters on the relative amount (RA) remaining when a pesticide reaches $2 \mathrm{~m}$ (6.6 ft) soil depth for known site, system, and irrigation schedule.

\section{SPRINKLER IRRIGATION}

Previously in our analysis, we used the $(\mathrm{Zreq} / \mathrm{Ha})$ approach to determine a field average applied depth of water. Here we compare that analysis with a more detailed approach. We compare this field average applied depth with the average of 10 normally distributed applied water depths. To do this, the field is divided into 10 incremental subareas of equal size. Using a normal distribution approach for the entire field, the appropriate applied depth was determined for each subarea under a normal curve. Then these 10 applied depths were averaged. Assumed was a uniformity coefficient (UC) of $60 \%$, and $80 \%$ of the field area adequately irrigated. A poor uniformity coefficient of $60 \%$ was selected because it demonstrated the greatest variations among applied water depths. This combination of UC and fraction of area adequately irrigated gives a distribution coefficient (Ha) of 0.578 (Table 1). The average applied depth (Vi) for the entire field is computed by dividing Zreq ( $45 \mathrm{~mm}$ or $1.8 \mathrm{in}$.) by $\mathrm{Ha}(0.578)$. Thus, $\mathrm{Vi}$ is estimated as $78 \mathrm{~mm}(3.1 \mathrm{in}$.$) . This average applied$ water depth is used to develop a normal curve and then to compute each individual applied water depth cumulatively for each of the 10 subareas of the field.

These 10 applied water depths were then input into 10 different CMLS simulations. Aldicarb, one of the most

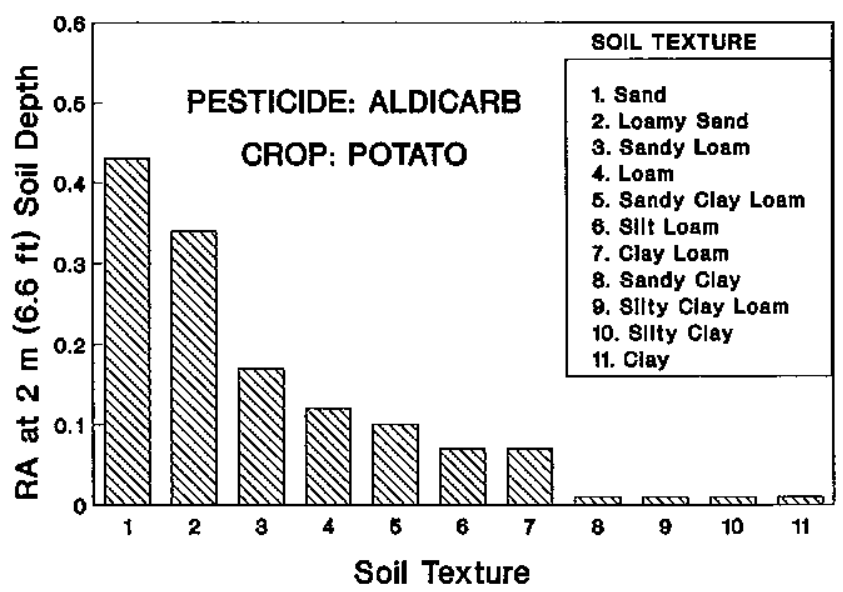

Figure 5-Effects of various soil textures on relative amount (RA) of aldicarb remaining in the soil at a depth of $2 \mathrm{~m}(6.6 \mathrm{ft})$. 
TABLE 2. Pesticide movement comparison under spritakler irrigation

\begin{tabular}{|c|c|c|c|c|c|c|c|}
\hline \multirow{2}{*}{$\begin{array}{l}\text { Row } \\
\text { No. }\end{array}$} & \multirow{2}{*}{$\begin{array}{c}\text { Pesticide } \\
\text { Name }\end{array}$} & \multirow[b]{2}{*}{$\begin{array}{c}\text { Area } \\
(\%)\end{array}$} & \multirow[b]{2}{*}{$\begin{array}{c}d \\
(m m)\end{array}$} & \multicolumn{4}{|c|}{ Relative Ambunt Remaining At } \\
\hline & & & & $1.0 \mathrm{~m}$ & $1.5 \mathrm{~m}$ & $2.0 \mathrm{~m}$ & $3.0 \mathrm{~m}$ \\
\hline 1 & Aldicarb & 10 & 16 & 0.0000 & 0.0000 & 0.0000 & 0.0000 \\
\hline 2 & Aldicarb & 10 & 37 & 0.0000 & 0.0000 & 0.0000 & 0.0000 \\
\hline 3 & Aldicarb & 10 & 51 & 0.0001 & 0.0000 & 0,0000 & 0.0000 \\
\hline 4 & Aldicarb & 10 & 63 & 0,0905 & 0.0001 & 0.0000 & $0.00 \times 0$ \\
\hline 5 & Aldicarb & 10 & 73 & 0.1649 & 0.0001 & 0.0001 & 0.0000 \\
\hline 6 & Aldicarb & 10 & 83 & 0.1984 & 0.0905 & 0.0001 & 0.0000 \\
\hline 7 & Aldicarb & 10 & 93 & 0.1984 & 0.1371 & 0.0686 & 0.0001 \\
\hline 8 & Aldicarb & 10 & 104 & 0.2679 & 0.1649 & 0.1114 & 0.0001 \\
\hline 9 & Aldicarb & 10 & 118 & 0.2679 & 0.1984 & 0.1371 & 0.0686 \\
\hline 10 & Aldicarb & 10 & 140 & 0.3455 & 0.1984 & 0.1649 & 0.1114 \\
\hline 11 & $\begin{array}{l}\text { Subareas } \\
\text { Average }\end{array}$ & & 78 & 0.1534 & 0.0790 & 0.0482 & 0.0180 \\
\hline 12 & Aldicarb & 100 & 78 & 0.1649 & 0.0686 & 0.0001 & 0.0000 \\
\hline Note: & $\begin{array}{l}\mathrm{d}=\text { depth of } \\
\text { To convert } \\
\mathrm{mm} / 25 \\
\mathrm{~m} \times 3.3=\end{array}$ & in & in $\mathrm{I}$ & $\begin{array}{l}\text { in. } \\
\text { the } f\end{array}$ & on & & \\
\hline
\end{tabular}

mobile and commonly found pesticides in groundwater was used. The results of these simulations are shown in Table 2. Also shown is the average of the 10 detailed simulations as well as the values computed by a single simulation using a $78 \mathrm{~mm}$ (3.1 in.) average applied water depth (the same approach as used in methodology). By comparing the last two rows in Table 2, we are comparing the average of 10 detailed simulations with the value computed by a single simulation.

The results are very similar down to a depth of $1.5 \mathrm{~m}$ $(5.0 \mathrm{ft})$ but are obviously different below that depth. This occurs because applied depth of water in each subarea is not uniform [ 16 to $140 \mathrm{~mm}(0.6$ to $5.5 \mathrm{in}$.)]. This nonuniformity produces some subareas with practically no deep percolation and pesticide movement and others with deep percolation and pesticide movement. Clearly, using the single average approach can give misleading results with increasing depth, if the uniformity coefficient is low. Underestimation can also become more important if preferential flow, which is not included in the model, is present causing a portion of the soil matrix to be bypassed during flow. The single depth approach is more accurate with higher irrigation uniformity (higher uniformity coefficients).

Figure 6 shows the influence of the different subarea percolation depths (from Table 2) upon aldicarb movement. Clearly, the pesticide will be much more prone to reach a water table at $2 \mathrm{~m}(6.6 \mathrm{ft})$ depth in some parts of a homogeneous field than in others.

\section{SUMMARY}

Procedures were developed for aiding environmentally safe pesticide/irrigation management. These required simulation of effects of sprinkler irrigation design, pesticide characteristics (partition coefficient and half-life), and soil type on pesticide leaching. First is design of a sprinkler irrigation system for a particular site and pesticide. This enables selection of the uniformity coefficient-percent area adequately watered combinations that avoid excessive pesticide movement. Second is selection of appropriate pesticides for a particular site, crop, and sprinkler design. This permits determining the

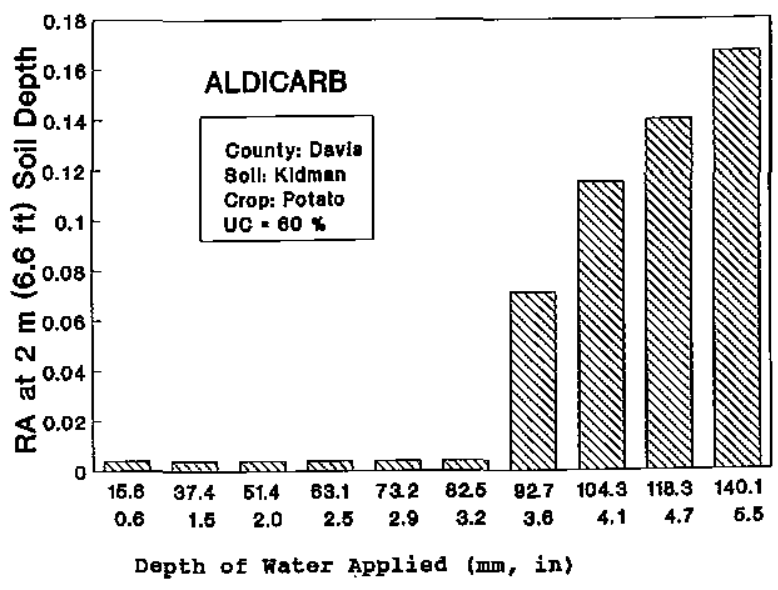

Figure 6-Effect of various applied water depths on relative amount (RA) of aldicarb remaining in the soil when it reaches to a depth of $2 \mathrm{~m}(6.6 \mathrm{ft})$.

threshold partition coefficients or half-lives for environmental safety at a particular site.

Analysis also revealed that using field average infiltration predicts inaccurate pesticide RA values at deeper soil depths. However, for shallow soil depths or irrigation system of good uniformity, the field average approach is acceptable.

A combination of BMPs (best management practices) such as efficient sprinkler system design, management, and selection of less mobile pesticides, will minimize the potential for groundwater contamination and associated environmental hazards.

ACKNowledgment. This research was supported by the Utah Agricultural Experiment Station, Utah State University, Logan. Approved as Journal Paper No. 4160.

\section{REFERENCES}

Aller, L., B. Truman, J. H. Lehr and R. J. Petty. 1985. DRASTIC: A standardized system for evaluating ground water pollution potential using hydrogeologic settings. USEPA/600/2-85/018, U.S. Environmental Protection Agency, Washington, DC.

Christensen, J. E. 1942. Irrigation by sprinkler. California Agricultural Experiment Station, Bulletin 670.

Ehteshami, M., R. C. Peralta, H. Eisele, H. M. Deer and T. Tindall. 1991. Assessing pesticide contamination to groundwater: A rapid approach, Journal of Groundwater (November-December).

Eisele, H., M. Ehteshami, R. C. Peralta, H. M. Deer and T. Tindall. 1989. Agricultural pesticide hazard to groundwater in Utah, IIC-89/1 A, Vols. I-II. Agricultural and Irrigation Engineering Department, Utah State University, Logan.

Hart, W. E. and W. N. Reynolds. 1965. Analytical design of sprinkler systems. Transactions of the ASAE 8(2):83-89.

Lau, L. S. and J. F. Mink. 1987. Organic contamination of groundwater: A learning experience. Journal of American Water Works Association 79(8):37-42.

Leonard, R. A., A. Shirmohammadi, A. W. Johnson and L. R. Marti. 1988. Pesticides transport in shallow groundwater. Transactions of the ASAE 31(3):776-788.

Nofziger, D. L. and A. G. Hornsby. 1986. A microcomputerbased management tool for chemical movement in soil. Applied Agricultural Research 1(1):50-56. 
1988. Chemical movement in layered soils: User's Manual, Agricultural Experiment Station, Division of Agriculture, Oklahoma State University, Stillwater.

Oki, D. S. and T. W. Giambelluca. 1987. DBCP, EDB, and TCP contamination of groundwater in Hawaii. Groundwater 25(6): 693-702.

Pimentel, D. and L. Levitan. 1986. Pesticides: Amounts applied and amounts reaching pest. BioScience 36:86-91.

Pionke, H. B., D. E. Glotfelty, A. D. Lucas and J. B. Urban. 1988. Pesticide contamination of ground water in the Mahantango Creek Watershed. Journal of Environmental Quality 17:76-84.

Sum, M. 1986. Groundwater: Many diagnoses, few remedies. Science 232:1490-1493.
USEPA. 1987. Agricultural chemicals in groundwater: Proposed strategy. U.S. Environmental Protection Agency, Office of Pesticide and Toxic Substances, Washington, DC.

Waddell, K. M. 1987. Utah groundwater quality. U.S. Geological Survey, Open-File 87-0757.

Zaki, M. H., D. Morgan and D. Harris. 1982. Pesticides in groundwater: The aldicarb story in Suffolk County, NY. American Public Health 72:1391-1395. 
